\title{
Soluble CD40L is associated with increased oxidative burst and neutrophil extracellular trap release in Behçet's disease
}

Sandro Félix Perazzio ${ }^{1,2,3^{*}}$, Paulo Vitor Soeiro-Pereira ${ }^{4,5}$, Viviane Cardoso dos Santos ${ }^{1}$, Marlon Vilela de Brito ${ }^{6}$, Bruno Salu' ${ }^{6}$, Maria Luiza Vilela Oliva ${ }^{6}$, Anne Margherite Stevens $^{3}$, Alexandre Wagner Silva de Souza ${ }^{1,2}$, Hans D. Ochs ${ }^{3}$, Troy R. Torgerson ${ }^{3}$, Antonio Condino-Neto ${ }^{4}$ and Luis Eduardo Coelho Andrade ${ }^{1,2}$

\begin{abstract}
Background: Studies have suggested that soluble factors in plasma from patients with active (aBD) and inactive (iBD) Behçet's disease (BD) stimulate neutrophil function. Soluble CD40 ligand (sCD40L) is an important mediator of inflammation in BD. Its expression and effect on neutrophil oxidative burst and neutrophil extracellular trap (NET) release have not been characterized. In this study, we sought to investigate the role of plasma and the CD40L pathway on NET release and the oxidative burst profile in patients with aBD and BBD.

Methods: Neutrophils and peripheral blood mononuclear cells (PBMCs) were obtained from patients with aBD $(n=30)$, patients with $\mathrm{BDD}(n=31)$, and healthy control subjects ( $\mathrm{HC} ; n=30)$. SCD40L plasma concentration was determined in individual samples. A pool of plasma for each group was created. In some experiments, plasma pools were treated with recombinant CD40 (rhCD40-mulg) for sCD40L blockade. NET release and $\mathrm{H}_{2} \mathrm{O}_{2} / \mathrm{O}_{2}^{-}$production were determined after stimulation with phorbol 12-myristate 13-acetate, SCD40L, or plasma pool. Flow cytometric analysis was performed to evaluate the expression of (1) CD40, Mac-1, and phosphorylated NF-KB p65 on neutrophils and monocytes and (2) CD40L on activated T cells and platelets. CD40L gene expression in PBMCs was determined by qRT-PCR.

Results: SCD40L plasma levels were significantly higher in patients with iBD (median 17,234, range 2346-19,279 pg/ml) and patients with $\mathrm{aBD}$ (median 18,289, range 413-19,883 pg/ml) than in HCs (median 47.5, range 33.7-26.7 pg/ml; $p<0$. 001). NET release was constitutively increased in $\mathrm{BD}$ compared with $\mathrm{HC}$. NET release and $\mathrm{H}_{2} \mathrm{O}_{2} / \mathrm{O}_{2}^{-}$were higher after stimulation with sCD40L or BD plasma and decreased after SCD40L blockade. Mac-1 expression was constitutively increased in neutrophils of patients with aBD ( $88.7 \pm 13.2 \%$ of cells) and patients with iBD ( $89.2 \pm 20.1 \%$ of cells) compared with HC $(27.1 \pm 18.8 \%$ of cells; $p<0.01)$. CD40 expression on phagocytes and CD40L expression on platelets were similar in the three groups. PBMCs as well as nonactivated and activated $C D 4^{+} \mathrm{T}$ cells from patients with BD showed higher CD40L expression.
\end{abstract}

Conclusions: Plasma from patients with aBD exerts a stimulus on NET release and oxidative burst, probably induced by SCD40L.

Keywords: Behçet's disease, Neutrophil activation, sCD40L, CD40L pathway, Oxidative burst, Neutrophil extracellular traps

\footnotetext{
* Correspondence: sperazzio@yahoo.com.br

'Division of Rheumatology, Escola Paulista de Medicina, Federal University of

Sao Paulo, Rua Botucatu 740, $3^{\circ}$ Andar, 04023-062 Sao Paulo, SP, Brazil

${ }^{2}$ Fleury Group - Research and Development, Avenida General Valdomiro de

Lima, 508, 04344-070 Sao Paulo, SP, Brazil

Full list of author information is available at the end of the article
} 


\section{Background}

The pathogenesis of Behçet's disease (BD) is unknown; however, there are pieces of evidence pointing to increased neutrophil activation in patients with BD that can be clinically correlated with the pathergy phenomenon [1]. Phagocyte functional abnormalities possibly involved in $\mathrm{BD}$ include cytokine production [2], oxidative burst [3], and phagocytic $[4,5]$ and microbicidal activity [6], but divergent results have been reported by different authors $[1,4,5,7,8]$. Our group recently reported on the heterogeneity in $\mathrm{BD}$ pathophysiology by showing that only patients with severe active BD exhibit evidence of constitutive neutrophil activation judged on the basis of oxidative burst activity and cytokine production [9].

Although several pieces of evidence point to participation of neutrophils in BD, evaluation of neutrophil extracellular trap (NET) formation in BD has not been investigated. Moreover, it is unclear whether phagocyte activation in patients with BD occurs constitutively, mainly in those carrying HLA-B51 [3], or if it is secondary to an as yet unknown stimulus $[10,11]$. Also, has not been defined whether the neutrophil hyperactive state is induced by some soluble serum or tissue factor or if BD neutrophils or other cell subtypes produce soluble inflammatory mediators carried by plasma, as previously suggested for specific phagocyte functions, such as chemotaxis [10] and oxidative burst [11].

Soluble CD40 ligand (sCD40L) is a cleaved form of CD40L present in the plasma. Its membrane-bound analogue is involved in immunoglobulin isotype switching, B-cell differentiation, antigen-presenting cell activation, T-cell modulation, and thrombocyte aggregation [12]. The major source of SCD40L is activated platelets, but activated $\mathrm{T}$ cells, macrophages, endothelial cells, and smooth muscle cells also contribute to SCD40L synthesis and shedding [13].

Fernández-Bello et al. [14] showed higher levels of plasma and platelet-derived sCD40L in a group of patients with $\mathrm{BD}$, although no differences in platelet activation or platelet-leukocyte aggregate formation were observed. In normal mouse neutrophils, sCD40L strongly stimulates the oxidative burst via a CD40-dependent phosphoinositide 3kinase/NF- $\mathrm{B}$ p pathway [15]. Additionally, platelet-derived sCD40L stimulates expression of the leukocyte-specific $\beta_{2}$ integrin Mac-1 in neutrophils and thereby further promotes neutrophil adhesion and migration [15]. Therefore, it is possible that elevated plasma sCD40L contributes to the characteristic phagocyte hyperactivity in $\mathrm{BD}$.

It has been postulated that BD may be a form of autoinflammatory disease [16]. Interestingly, although some pieces of evidence point to neutrophil hyperactivation in $\mathrm{BD}$, it is not clear if this is a primary (constitutive) phenomenon or if it is secondary to putative soluble factors. We hypothesize that $\mathrm{sCD} 40 \mathrm{~L}$ carried at increased levels by the plasma of patients with $\mathrm{BD}$ is associated with systemic phagocyte activation. In the present study, we investigated the role of plasma from patients with $\mathrm{BD}$ and sCD40L on NET release and oxidative burst profiles in neutrophils and peripheral blood mononuclear cells (PBMCs) from patients with active Behçet's disease (aBD) and patients with inactive Behçet's disease (iBD).

\section{Methods}

\section{Study subjects and diagnostic criteria}

This study included three main subject groups: (1) 30 healthy control subjects (HC), (2) 31 patients with iBD, and (3) 30 patients with aBD. All patients with BD met the International Study Group for Behçet's Disease criteria [17]. Active BD was defined as a score $\geq 2$ and $\mathrm{iBD}$ as a score of zero on the Simplified Behçet's Disease Current Activity Form adapted for Portuguese by the Sociedade Brasileira de Reumatologia (sBR-BDCAF) [18]. The HC group comprised healthy adult volunteers from the hospital staff with no evidence or family history of autoimmune disease or immunodeficiency. Additionally, for some experiments, we used samples derived from 25 patients with sepsis (PSs), 27 patients with inactive pediatric systemic lupus erythematosus (iSLE), and 27 patients with active pediatric systemic lupus erythematosus (aSLE). The PS group, a positive control group for neutrophil activation, consisted of adult inpatients meeting the sepsis criteria of the American College of Chest Physicians/Society of Critical Care Medicine Consensus Conference [19]. The SLE group consisted of pediatric patients meeting the American College of Rheumatology criteria for SLE [20]. Patients scoring $\geq 6$ on the Systemic Lupus Erythematosus Disease Activity Index [21] were considered to have active disease, and those scoring zero were considered to have inactive disease. The study was approved by the institutional ethics review boards of Universidade Federal de São Paulo (CEP 0013/11) and Seattle Children's.

\section{Plasma pools}

Plasma pools for each group were assembled by mixing plasma samples derived from heparinized blood drawn from each subject enrolled in the study. Additionally, plasma from four different X-linked hyper immunoglobulin $M$ patients collected at the immunology outpatient clinic of the University of Sao Paulo was used to constitute a pool of hyper immunoglobulin $\mathrm{M}$ plasma (HIgM). All pools were stored in aliquots at $-80{ }^{\circ} \mathrm{C}$.

\section{RNA extraction and complementary DNA synthesis}

RNA was isolated by standard RNA extraction using TRIzol $^{\odot}$ Reagent (Life Technologies, Carlsbad, CA, USA) and transformed into complementary DNA (cDNA) by using the SuperScript One-Step RT-PCR 
System with Platinum Taq DNA polymerase (Life Technologies) using a thermocycler (Eppendorf, Hamburg, Germany).

\section{Quantification of cytokine and soluble receptors in plasma}

After donation, blood samples were immediately spun at $2500 \mathrm{rpm}$ for 15 minutes at room temperature, and 2-ml plasma aliquots with $40 \mu \mathrm{l}$ of dipeptidyl peptidase-4 protease inhibitor (Merck Millipore, Billerica, MA, USA) were stored at $-80{ }^{\circ} \mathrm{C}$. All plasma samples were thawed only once for determination of the concentration of 13 soluble receptors (HSCR-32 K; Merck Millipore) and 64 cytokines (HCYTOMAG-60 K and HCYP2MAG-62 K; Merck Millipore) by addressable laser bead immunoenzyme assay according to the manufacturer's specifications and read using the Luminex MAGPIX ${ }^{\odot}$ System 40-072 (Merck Millipore). sCD40L plasma levels were subsequently assessed by enzyme-linked immunosorbent assay (ELISA) using the Human sCD40L Platinum ELISA kit (eBioscience, San Diego, CA, USA) according to the manufacturer's specifications and read at $\lambda=450$ / $570 \mathrm{~nm}$ in a VICTOR X3 2030 multilabel ELISA reader (PerkinElmer, Singapore).

\section{Hydrogen peroxide and superoxide anion quantification}

Neutrophils and PBMCs were separated by density gradient separation using dextran and Ficoll-Hypaque 1077, respectively. Cells were stimulated with (1) $30 \mathrm{ng} / \mathrm{ml}$ phorbol 12-myristate 13-acetate (PMA; Sigma-Aldrich, St. Louis, MO, USA), (2) $50 \mu \mathrm{l}$ of pooled plasma (from $\mathrm{HCs}$, patients with iBD, or patients with $\mathrm{aBD}$ ) with or without $2 \mu \mathrm{g} / \mathrm{ml}$ recombinant CD40 (rhCD40-muIg; (R\&D Systems, Minneapolis, MN, USA), (3) $50 \mu \mathrm{l}$ of pooled plasma from HIgM patients, or (4) $100 \mathrm{ng} / \mathrm{ml} \mathrm{rh}$ sCD40L (Life Technologies). Hydrogen peroxide and superoxide production was determined by luminol/lucigenin chemiluminescence intensity and quantified for $2 \mathrm{~h}$ at $37{ }^{\circ} \mathrm{C}$ during the readout in the VICTOR X3 2030 multilabel plate reader as described previously [22, 23]. Each well was read for 0.5 seconds every 50 seconds, and the results were expressed as a kinetic curve of relative light units on the $x$-axis and time in minutes on the $y$-axis. The analysis was based on the AUC.

\section{Expression of nicotinamide adenine dinucleotide phosphate oxidase components}

Gene expression of nicotinamide adenine dinucleotide phosphate (NADPH) oxidase components was determined by qRT-PCR as described previously [22]. (Primers are shown in Additional file 1: Table S1.) Data were acquired and analyzed using a ViiA 7 RT-PCR system (Thermo Fisher Scientific, Waltham, MA, USA).
Protein expression of NADPH oxidase subunit protein expression was determined by flow cytometry. Briefly, $100 \mu \mathrm{l}$ of whole blood was diluted with $100 \mu \mathrm{l}$ of PBS and incubated with $30 \mathrm{ng} / \mathrm{ml}$ PMA or $50 \mu \mathrm{l}$ of pooled plasma (from $\mathrm{HCs}$, patients with $\mathrm{iBD}$, or patients with $\mathrm{aBD}$ ) for $6 \mathrm{~h}$ in a $5 \% \mathrm{CO}_{2}$ atmosphere at $37{ }^{\circ} \mathrm{C}$. For gp91-phox and p22 subunit evaluation, the samples were stained with $2 \mu \mathrm{l}$ of anti-gp91-phox-fluorescein isothiocyanate (Santa Cruz Biotechnology, Dallas, TX, USA) and $2 \mu \mathrm{l}$ of anti-p22-phycoerythrin (PE) (Santa Cruz Biotechnology), respectively, for 30 minutes in the dark. For p40, p47, and p67 subunit evaluation, the samples were initially fixed with $50 \mu \mathrm{l}$ of BD Cytofix fixation buffer (BD Biosciences, San Jose, CA, USA) and then permeabilized with $50 \mu \mathrm{l}$ of BD Phosflow Perm Buffer III (BD Biosciences) according to the manufacturer's instructions. Then, the samples were stained with $2 \mu \mathrm{l}$ of anti-p40-AF488 (Santa Cruz Biotechnology), $2 \mu \mathrm{l}$ of anti-p47-AF647 (Santa Cruz Biotechnology), and $2 \mu \mathrm{l}$ of anti-p67-PE (Santa Cruz Biotechnology). Using a FACSAria III flow cytometer (BD Biosciences), we observed that monocytes and neutrophils were gated by forward and side scatter. Acquired data were analyzed using FlowJo software (FlowJo, Ashland, OR, USA).

\section{Protein expression of NF-kB phosphorylated p65 subunit} Assessment of NF-kB p65 subunit phosphorylation was performed by flow cytometry as previously described [24] following incubation with $30 \mathrm{ng} / \mathrm{ml}$ PMA or $50 \mu \mathrm{l}$ of pooled plasma (from $\mathrm{HCs}$, patients with iBD, or patients with aBD) for 15 minutes in a $5 \% \mathrm{CO}_{2}$ atmosphere at $37^{\circ} \mathrm{C}$.

\section{NET formation}

NET release was determined as previously described [25] after stimulation with $30 \mathrm{ng} / \mathrm{ml}$ PMA, $100 \mathrm{ng} / \mathrm{ml}$ rh-sCD40L, or $50 \mu \mathrm{l}$ of pooled plasma (from $\mathrm{HCs}$, patients with iBD, or patients with $\mathrm{aBD}$ ) with or without $2 \mu \mathrm{g} / \mathrm{ml}$ rhCD40-muIg. Cells were stained with primary anti-histone $\mathrm{H} 2 \mathrm{~A} / \mathrm{B}$ (kindly provided by Dr. Arturo Zychlinsky, Max Planck Institute, Berlin, Germany) and anti-human neutrophil elastase monoclonal antibodies (Abcam, Cambridge, UK). Bisbenzimide (Life Technologies) was used for DNA labeling. Three random microscopic fields $(\times 400$ magnification) were photographed with $\mathrm{a} \times 40$ or $\times 63$ lens objective and 17, 20, and 21 high-efficiency filters for each fluorochrome, respectively. Total NET area in each photo was calculated using ZEN lite 2012 (black edition) software (Carl Zeiss, Oberkochen, Germany).

\section{CD40L protein and gene expression}

CD40L protein expression was determined by flow cytometry as previously described $[14,26]$. Platelets were 
obtained and assessed by flow cytometry for CD40L protein expression before and after stimulation with $0.2 \mathrm{U} /$ $\mathrm{ml}$ thrombin for 5 minutes at $37^{\circ} \mathrm{C}$ in a $5 \% \mathrm{CO}_{2}$ atmosphere [14]. CD40L protein expression in monocytes and in $\mathrm{CD}^{+}$and $\mathrm{CD}^{+} \mathrm{T}$ lymphocytes was determined by flow cytometry before and after stimulation with $1.5 \mu \mathrm{M}$ ionomycin (Sigma-Aldrich) and/or $25 \mathrm{ng} / \mathrm{ml}$ PMA [26]. CD40L gene expression in PBMCs was determined before and after stimulation with $10 \mathrm{ng} / \mathrm{ml}$ PMA for $3 \mathrm{~h}$ using the TaqMan ${ }^{\circ}$ Gene Expression qRT-PCR Assay for CD40L (Thermo Fisher Scientific). cDNA levels were normalized to the expression of glyceraldehyde 3phosphate dehydrogenase (Thermo Fisher Scientific).

\section{Statistical analysis}

Continuous variables were evaluated using the Kolmogorov-Smirnov test and analyzed using Student's $t$ test (normal distribution) or the Mann-Whitney $U$ test (nonparametric distribution). Qualitative parameters were analyzed using the chi-square test and Fisher's exact test when appropriate. Multiparametric analyses were conducted with one-way analysis of variance (ANOVA) followed by Bonferroni posttests when appropriate. The statistical inference level was set at 0.05 .

\section{Results}

\section{Study subject characteristics}

The female-to-male ratios were 14:16 in the aBD group and $15: 16$ in the $\mathrm{iBD}$ group, with ages ranging from 20 to 57 years $(36.13 \pm 11.02)$ and from 20 to 55 years $(40.96 \pm 9.72)$, respectively. The female-to-male ratios were 18:12 in the HC group, 14:11 in the PS group, 18:9 in the iSLE group, and 22:5 in the aSLE group, with age ranges varying from 24 to 62 years $(35.63 \pm 9.49), 20$ to 82 years $(46.00 \pm 25.76), 6$ to 18 years $(14.32 \pm 2.96)$, and 7 to 20 years $(15.12 \pm 3.48)$, respectively. The HIgM plasma pool was constituted of plasma from four Xlinked hyper-IgM male patients aged 4, 5, 7, and 8 years. Patients with $\mathrm{BD}$ and control subjects did not differ regarding gender distribution. The $\mathrm{HC}, \mathrm{iBD}, \mathrm{aBD}$, and PS groups did not differ regarding age distribution. The iSLE, aSLE, and HIgM groups were significantly younger than the other groups.

Miscellaneous comorbidities (osteoarthritis, osteopenia/osteoporosis, glaucoma, arterial hypertension, dyslipidemia, chronic obstructive pulmonary disease, and epilepsy, among others) were equally present in patients with $\mathrm{iBD}(n=22 ; 70.96 \%)$ and patients with $\mathrm{aBD}(n=19$; $63.33 \%)(p=0.59)$. The clinical characteristics and therapeutic regimens of patients with $\mathrm{BD}$ are shown in Table 1. There were no significant differences between patients with $\mathrm{aBD}$ and patients with iBD regarding previous disease manifestations. All patients were under treatment at the time of the study. As expected, the number of patients with aBD receiving cyclophosphamide or high doses of corticosteroids was higher than among patients with iBD.

\section{NET release is increased by neutrophils from patients with $\mathrm{BD}$ and is further stimulated by plasma from patients with BD}

Neutrophils from patients with BD showed a higher rate of spontaneous NET release than those from HCs, although no difference was observed after stimulation with PMA (Fig. 1a). When stimulated with plasma, neutrophils from patients with BD released more NET than HCs' neutrophils (Fig. 1b). Moreover, NET release was more strongly stimulated by plasma from patients with aBD than by plasma from HCs or patients with iBD (Fig. 1c). Figure 2 shows photomicrographs illustrating the results.

\section{Plasma from patients with BD stimulates oxidative burst and NADPH oxidase protein expression}

Superoxide and hydrogen peroxide production in resting phagocytes was similar in patients with $\mathrm{BD}$ and $\mathrm{HCs}$. Plasma from patients with BD, but not from HCs, stimulated oxidative burst in phagocytes from normal individuals and patients with BD (Fig. 3a-d). Interestingly, neutrophils from $\mathrm{HCs}$ produced more superoxide (Fig. 3a) and hydrogen peroxide (Fig. 3b) after stimulation with aBD plasma than with $\mathrm{BBD}$ and $\mathrm{HC}$ plasma. In general, PMA stimulated higher superoxide production in neutrophils than any other stimulus; however, hydrogen peroxide production by aBD neutrophils was higher after aBD plasma than after PMA stimuli, and hydrogen peroxide production by $\mathrm{iBD}$ neutrophils after PMA stimulation was equivalent to that observed with $\mathrm{BBD}$ or aBD plasma stimuli.

Similar results were also observed in PBMC assays, in which superoxide (Fig. 3c) and hydrogen peroxide production (Fig. 3d) were higher after BD plasma stimulation than after $\mathrm{HC}$ plasma stimulation. Remarkably, aBD plasma exerted a stronger effect than iBD plasma on superoxide production by PBMCs from $\mathrm{HCs}$ and were even comparable to PMA on aBD cells (Fig. 3c). In all the other comparisons, reactive oxygen species production by PMA-stimulated PBMCs was higher than with any other stimulus.

To determine whether the increased production of reactive oxygen species by BD neutrophils could be a result of increased expression of the NADPH oxidase subunits, we evaluated the level of subunit expression by both messenger RNA (mRNA) and protein analysis. Expression of each NADPH oxidase subunit gene was equivalent in resting neutrophils (Fig. 4a) and PBMCs (Fig. 4b) from HCs, patients with iBD, and patients with aBD. Cells from a group of 25 patients with severe sepsis 
Table 1 Distribution of patients with inactive and active Behçet's disease, according to clinical manifestations and medication use

\begin{tabular}{|c|c|c|c|c|}
\hline & $\mathrm{iBD}(n=3$ & & $\mathrm{aBD}(n=30)$ & \\
\hline & Current & Previous & Current & Previous \\
\hline Clinical manifestations & & & & \\
\hline Oral ulcers & 0 & $31(100)$ & $21(70.0)$ & $30(100)$ \\
\hline Genital ulcers & 0 & $28(90.3)$ & $5(16.7)$ & $24(80.0)$ \\
\hline Anterior uveitis & 0 & $14(45.2)$ & $11(36.7)$ & $8(26.7)$ \\
\hline Posterior uveitis & 0 & $10(32.3)$ & $7(23.3)$ & $11(36.7)$ \\
\hline Other ocular manifestations ${ }^{\mathrm{a}}$ & 0 & $5(16.1)$ & $4(13.3)$ & $5(16.7)$ \\
\hline Pseudofolliculitis & 0 & $18(58.1)$ & $6(20.0)$ & $11(36.7)$ \\
\hline Erythema nodosum & 0 & $15(48.4)$ & $8(26.7)$ & $14(46.7)$ \\
\hline CNS & 0 & $7(22.6)$ & $5(16.7)$ & $5(16.7)$ \\
\hline Gastrointestinal & 0 & $2(6.5)$ & 0 & $1(3.3)$ \\
\hline Cardiovascular & 0 & $5(16.1)$ & $3(10.0)$ & $4(13.3)$ \\
\hline Pathergy & $5(16.1)$ & & $2(6.7)$ & \\
\hline Others $^{b}$ & 0 & $13(41.9)$ & $5(16.7)$ & $9(30.0)$ \\
\hline Disease duration, years, median/minimum-maximum & $9 / 1-30$ & & $6 / 0-19$ & \\
\hline Age at BD onset, years, mean (SD) & $30.1 \pm 9.6$ & & $28.7 \pm 12.0$ & \\
\hline sBR-BDCAF, median/minimum-maximum & $0 / 0-0$ & & $3 / 2-4$ & \\
\hline Medications & $26(83.9)$ & $29(93.5)$ & $28(93.3)$ & $23(76.7)$ \\
\hline Colchicine & $14(45.2)$ & $11(35.5)$ & $15(50.0)$ & $5(16.7)$ \\
\hline Azathioprine & $14(45.2)$ & $10(32.5)$ & $16(53.3)$ & $4(13.3)$ \\
\hline Thalidomide & $2(6.5)$ & $7(22.6)$ & $3(10.0)$ & $3(10.0)$ \\
\hline Methotrexate & $3(9.7)$ & $6(19.4)$ & $1(3.3)$ & $3(10.0)$ \\
\hline Cyclophosphamide & $0^{*}$ & $7(22.6)$ & $5(16.7)^{c}$ & $2(6.7)$ \\
\hline Penicillin $\mathrm{G}$ benzathine & $4(12.9)$ & $7(22.6)$ & $4(13.3)$ & $4(13.3)$ \\
\hline Anti-TNF & $5(16.1)$ & 0 & $1(3.3)$ & $1(3.3)$ \\
\hline Corticosteroids & & & & \\
\hline High dose & $5(16.1)^{d}$ & $13(41.9)$ & $15(50.0)^{d}$ & $12(40.0)$ \\
\hline Low dose & $5(16.1)$ & $18(58.1)$ & $6(20.0)$ & $10(33.3)$ \\
\hline Cyclosporine & $1(3.2)$ & $6(19.4)$ & $6(20.0)$ & $5(16.7)$ \\
\hline Pentoxifylline & $2(6.5)$ & $2(6.5)$ & $1(3.3)$ & $2(6.7)$ \\
\hline Minocycline & 0 & $3(9.7)$ & 0 & 0 \\
\hline Dapsone & 0 & 0 & 0 & $1(3.3)$ \\
\hline Chlorambucil & 0 & $2(6.5)$ & 0 & $1(3.3)$ \\
\hline Sulfasalazine & 0 & $1(3.2)$ & 0 & 0 \\
\hline
\end{tabular}

Abbreviations: $a B D$ Active Behçet's disease, $B D$ Behçet's disease, $C N S$ Central nervous system, iBD Inactive Behçet's disease, $s B R$ - $B D C A F$ Simplified Behçet's Disease Current Activity Form adapted for Portuguese by the Sociedade Brasileira de Reumatologia, TNF Tumor necrosis factor

ancluded cases with optic neuritis, vitreous hemorrhage, sudden blindness, and so forth

${ }^{b}$ Other manifestations: BD-induced dementia, arthralgia/arthritis, folliculitis decalvans, and so forth

${ }^{c} p<0.05$

${ }^{\mathrm{d}} p<0.01$

were used as a positive control and, as expected, exhibited higher expression of gp91-phox, p22, p40, and p67 NADPH oxidase subunits. As for NADPH oxidase protein, the expression of the five subunits in neutrophils and monocytes increased significantly after stimulation with $\mathrm{aBD}$ or iBD plasma. Interestingly, plasma from HCs also caused an increase in NADPH oxidase protein expression, but plasma from patients with BD had a significantly stronger effect (Table 2).

CD40/CD40L pathway is associated with increased NET release and oxidative burst in patients with $\mathrm{BD}$

The above results indicate a possible soluble factor carried by the plasma from patients with $\mathrm{BD}$ that would be 

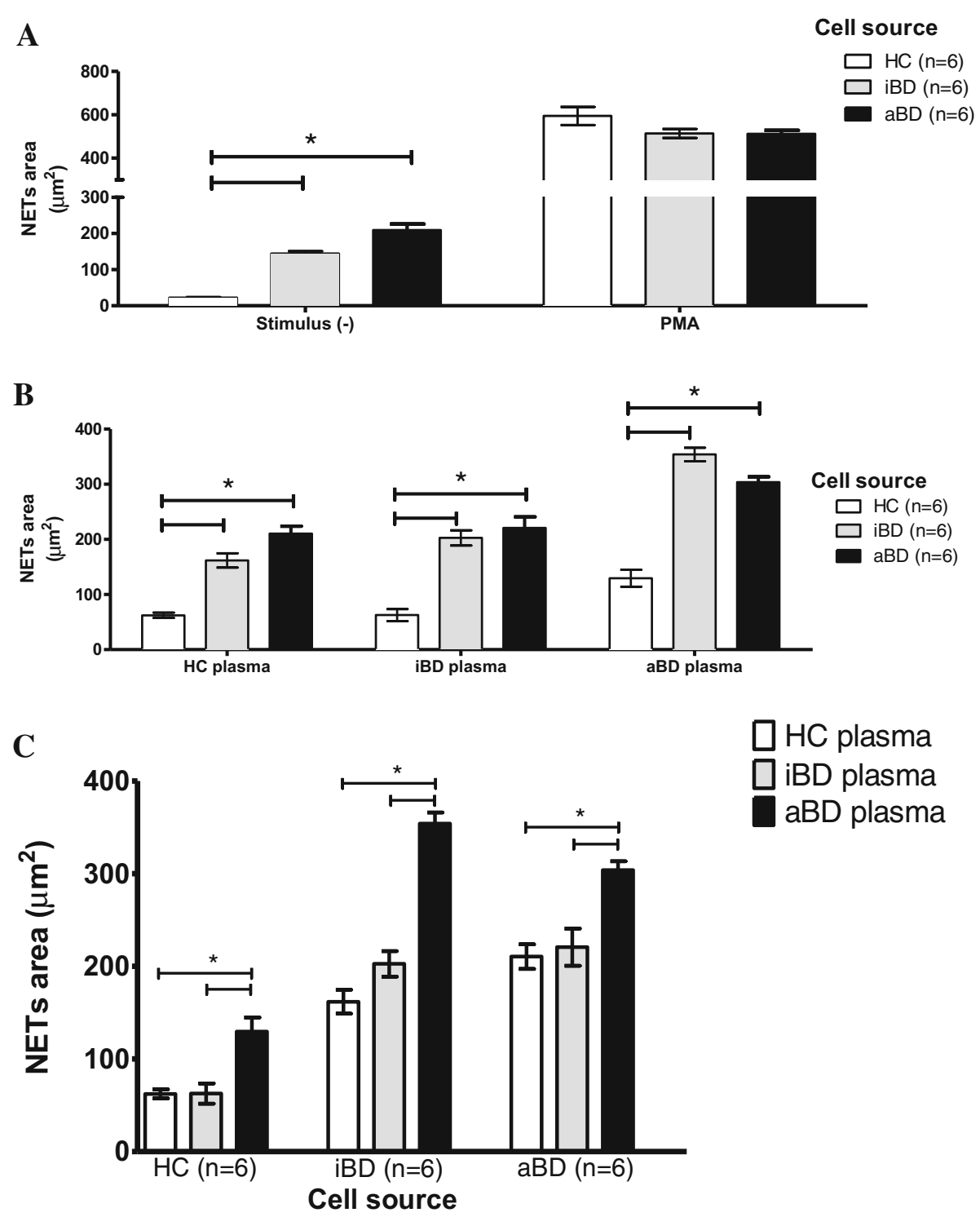

$* \mathrm{p}<0.05$

Fig. 1 Neutrophil extracellular trap (NET) release is increased in Behçet's disease (BD). a Resting neutrophils from healthy control subjects (HCs; $n=6$ ), patients with active Behçet's disease (aBD; $n=6)$, patients with inactive Behçet's disease (iBD; $n=6$ ), patients without stimulus, and after phorbol 12 myristate 13-acetate stimulation. $\mathbf{b}$ Effect of plasma from $\mathrm{HCs}$, patients with $\mathrm{BBD}$, and patients with $\mathrm{BBD}$ on NET release by neutrophils from HCs and patients with BD. (c) Plasma from patients with aBD exerted a stronger stimulus on NET formation by neutrophils from HC and patients with BD. Bars represent mean \pm SE. Statistical analysis was performed with one-way analysis of variance and the Bonferroni posttest

responsible for activating NET release and oxidative burst. In an effort to identify this factor, we determined the concentration of 64 cytokines and 13 soluble receptors in the plasma from patients with BD and from HCs by multiplex technology (Additional file 2: Table S2). Among the several factors that showed the greatest differences between $\mathrm{HC}$ and $\mathrm{BD}$ plasma, SCD40L was markedly higher in samples from patients with $\mathrm{BD}$ (Fig. 5a). This result was confirmed by ELISA, which demonstrated that $\mathrm{sCD} 40 \mathrm{~L}$ plasma levels from patients with $\mathrm{aBD}$ are significantly higher than those from HCs and patients with iBD (Fig. 5b). To gauge the comparative level of CD40L expression in patients with $\mathrm{BD}$, we quantified SCD40L in patients with iSLE and patients with aSLE, whose CD40L expression is known to be highly upregulated in $\mathrm{CD}^{+} \mathrm{T}$ cells and even aberrantly expressed on $\mathrm{CD}^{+} \mathrm{T}$ cells, B cells, and monocytes [27, 28]. Despite SCD40L levels being markedly elevated in aSLE, the levels observed in $\mathrm{aBD}$ were even higher. In patients with $\mathrm{iBD}$, sCD40L plasma levels were comparable to those in 


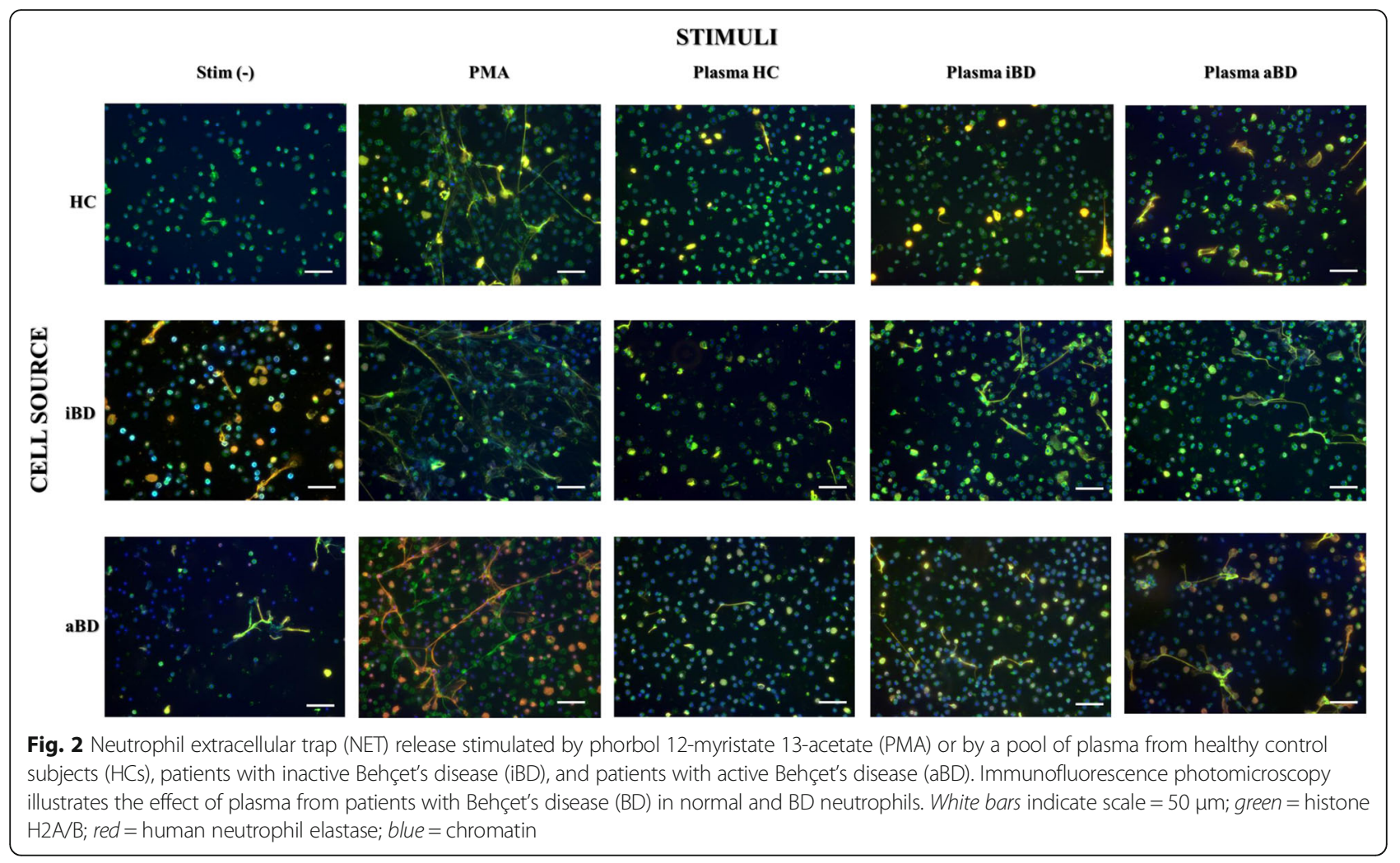

patients with aSLE and higher than those in HCs and patients with iSLE (Fig. 5b). It is remarkable that patients with $\mathrm{aBD}$ presented a wide range of $\mathrm{SCD} 40 \mathrm{~L}$ plasma levels, suggesting some heterogeneity in the pathophysiology of the disease. Of note, nonautoimmune diseases previously associated with high levels of sCD40L, such as myocardial infarction [29], atherosclerosis [30], and diabetes mellitus [31], were not observed in our cohort. Furthermore, the distribution of other risk factors for cardiovascular diseases, namely arterial hypertension $(\mathrm{iBD}=9.67 \%$ vs $\mathrm{aBD}=$ $20 \% ; p=0.3$ ) and dyslipidemia ( $\mathrm{iBD}=22.58 \%$ vs $\mathrm{aBD}=$ $6.66 \% ; p=0.14$ ), was not different between the two groups of patients.

We then investigated the hypothesis that $\mathrm{SCD} 40 \mathrm{~L}$ was the stimulating factor responsible for the increased NETosis and oxidative burst after stimulation with BD plasma. In in vitro experiments, we stimulated cells with recombinant $\mathrm{sCD} 40 \mathrm{~L}$ or with plasma from patients with $\mathrm{BD}$ in the presence or absence of rhCD40-mulg used as a specific sCD40L blocking agent. NET release was significantly reduced after sequestering $\mathrm{SCD} 40 \mathrm{~L}$ with rhCD40-muIg and increased when stimulated with recombinant sCD40L (Fig. 5c). Similarly, superoxide (Fig. 5d and f) and hydrogen peroxide (Fig. 5e and g) production by neutrophils (Fig. 5d and e) and PBMCs (Fig. 5f and g) from patients with iBD, patients with $\mathrm{aBD}$, and $\mathrm{HCs}$ was also significantly stimulated by sCD40L and decreased by sCD40L blockade. In addition,
sCD40L-poor plasma obtained from patients with CD40L deficiency (hyper-IgM plasma) was not able to increase oxidative burst (Fig. $5 \mathrm{~d}-\mathrm{g}$ ).

CD40L, Mac-1, and phosphorylated NF-кB p65 subunit are overexpressed in patients with BD

To determine the source of the elevated SCD40L in the plasma of patients with $\mathrm{BD}$, we evaluated expression by the normal cell sources of CD40L in peripheral blood. Although platelets are a major source of sCD40L, no difference in CD40L protein expression was observed in platelets from patients with $\mathrm{BD}$ compared with those of HCs (Fig. 6a). In contrast, on one hand, CD40L gene expression was strikingly increased in resting PBMCs from patients with $\mathrm{BD}$ compared with $\mathrm{HCs}$, but there was not an additional increase after PMA stimulation (Fig. 6b). On the other hand, the number of $\mathrm{CD} 4{ }^{+} \mathrm{CD} 40 \mathrm{~L}^{+} \mathrm{T}$ cells from patients with $\mathrm{BD}$ was significantly higher after combined PMA-ionomycin stimulation, suggesting that there is a larger preexisting pool of CD40L protein in $\mathrm{T}$ cells (Fig. 6c). Interestingly, contrary to previous observations in patients with lupus [27, 28], CD40L expression on $\mathrm{CD}^{+} \mathrm{T}$ cells and monocytes from patients with $\mathrm{BD}$ was not different from that observed in $\mathrm{HC}$ cells (Additional file 3: Figure S1). Additionally, macrophage integrin Mac-1, but not CD40 protein, was overexpressed in resting neutrophils (Fig. 6d) and monocytes (Fig. 6e) from patients with BD compared with those 


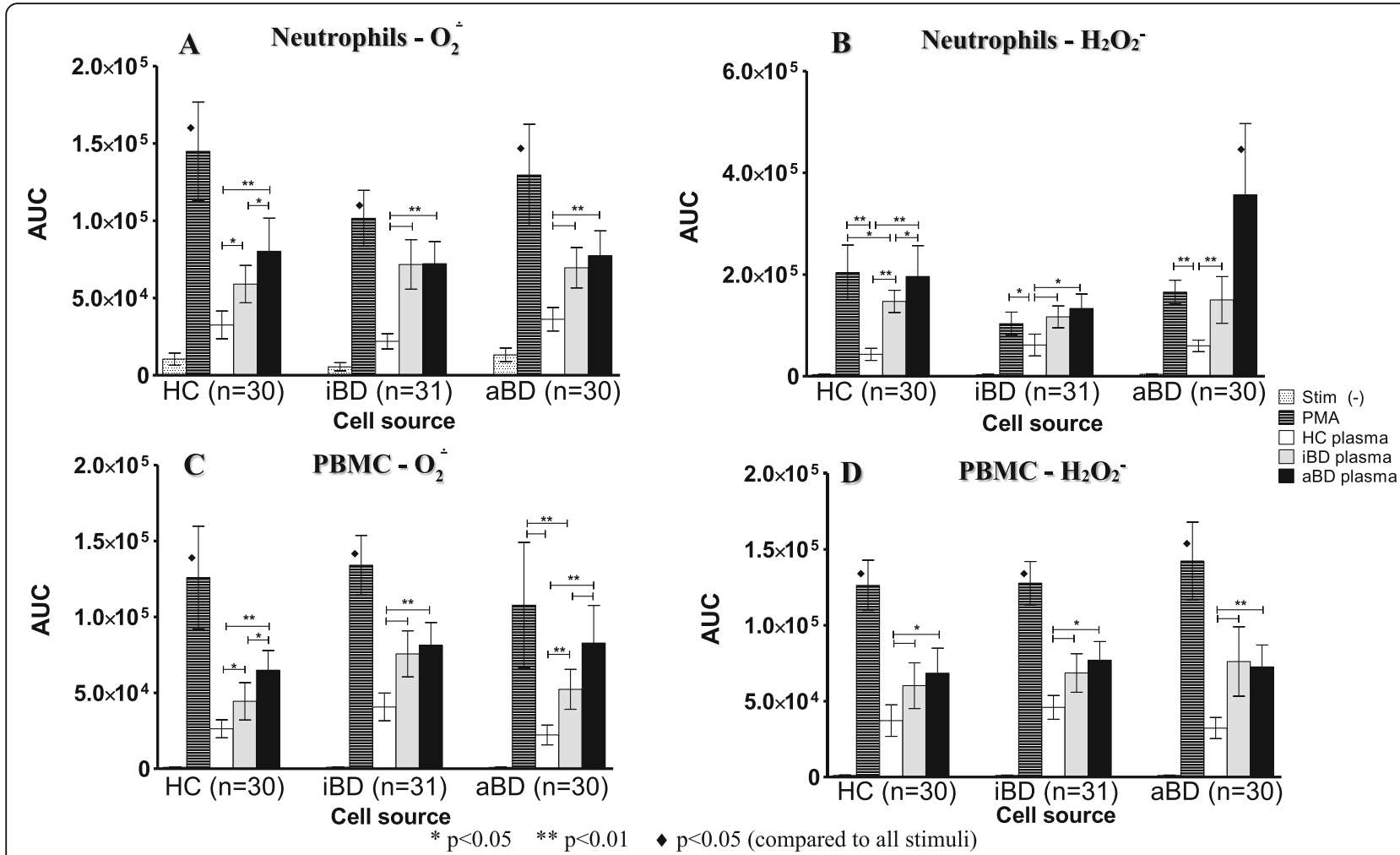

Fig. 3 Plasma from patients with Behçet's disease (BD) stimulates phagocyte oxidative burst activity. Superoxide (a and c) and hydrogen peroxide (b and $\mathbf{d}$ ) production by neutrophils ( $\mathbf{a}$ and $\mathbf{b})$ and peripheral blood mononuclear cells (PBMCs) (c and $\mathbf{d})$ from healthy control subjects (HCs; $n=$ 30), patients with active Behçet's disease (aBD; $n=30$ ), and patients with inactive Behçet's disease (iBD; $n=31$ ) after human plasma or phorbol 12myristate 13-acetate stimuli, calculated by the AUC. In general, BD plasma exerted a strong stimulus to oxidative burst by phagocytes from HCs, patients with $\mathrm{iBD}$, and patients with aBD. Bars represent mean $\pm \mathrm{SE}$. Statistical analysis was performed by one-way analysis of variance with the Bonferroni posttest

from HCs. Finally, phosphorylation of the NF-kB p65 subunit was constitutively increased in neutrophils and monocytes from patients with BD, suggesting chronic baseline activation (Fig. 6f) of these cells. Importantly, phosphorylation of the NF-kB p65 subunit was significantly increased in normal neutrophils and monocytes after stimulation with iBD or aBD plasma (Fig. 6g).

\section{Discussion}

In this study, we systematically evaluated several phagocyte functions in $\mathrm{BD}$, thus complementing previous investigations in which researchers assessed individual neutrophil functions in this disease [4, 8, 10, 32]. Previous findings demonstrating the absence of primary activation of $\mathrm{BD}$ phagocytes [9] and the stimulating effect of plasma from patients with $\mathrm{BD}$ on chemotactic function [10] and oxidative burst [11] of normal neutrophils corroborate our findings that a soluble plasma factor plays a relevant role in the neutrophil hyperactivity observed in $\mathrm{BD}$, which is the main contribution of the present study. NET release by neutrophils, but not the oxidative burst of phagocytes, was increased in nonstimulated cells from patients with BD. Stimulation with BD plasma induced a significant increase in both functions, in some instances comparable to a PMA-induced response. Interestingly, neutrophils from patients with aBD exhibited higher hydrogen peroxide production after stimulation with aBD plasma than other cells or stimuli, suggesting that cells from patients with active disease are in a "preactivated" state.

Several of the evaluated soluble mediators were increased in plasma from patients with $\mathrm{BD}$ in comparison to that from HCs; however, the elevation in sCD40L plasma levels in patients with BD was striking. Remarkably, aBD plasma exerted a stronger stimulus on NET release than iBD or HC plasma, correlating with the higher levels of sCD40L in aBD vs iBD. Moreover, the recapitulation of the stimulating effect of $\mathrm{BD}$ plasma on phagocyte function by treatment with rh-sCD40L and the inhibition by sCD40L blockade further support our interpretation that sCD40L carried in BD plasma is directly associated with some of the functional abnormalities observed in $\mathrm{BD}$ phagocytes. This was further supported by our demonstration that sCD40L-deficient plasma failed to stimulate hydrogen peroxide or superoxide production in similar experiments. 

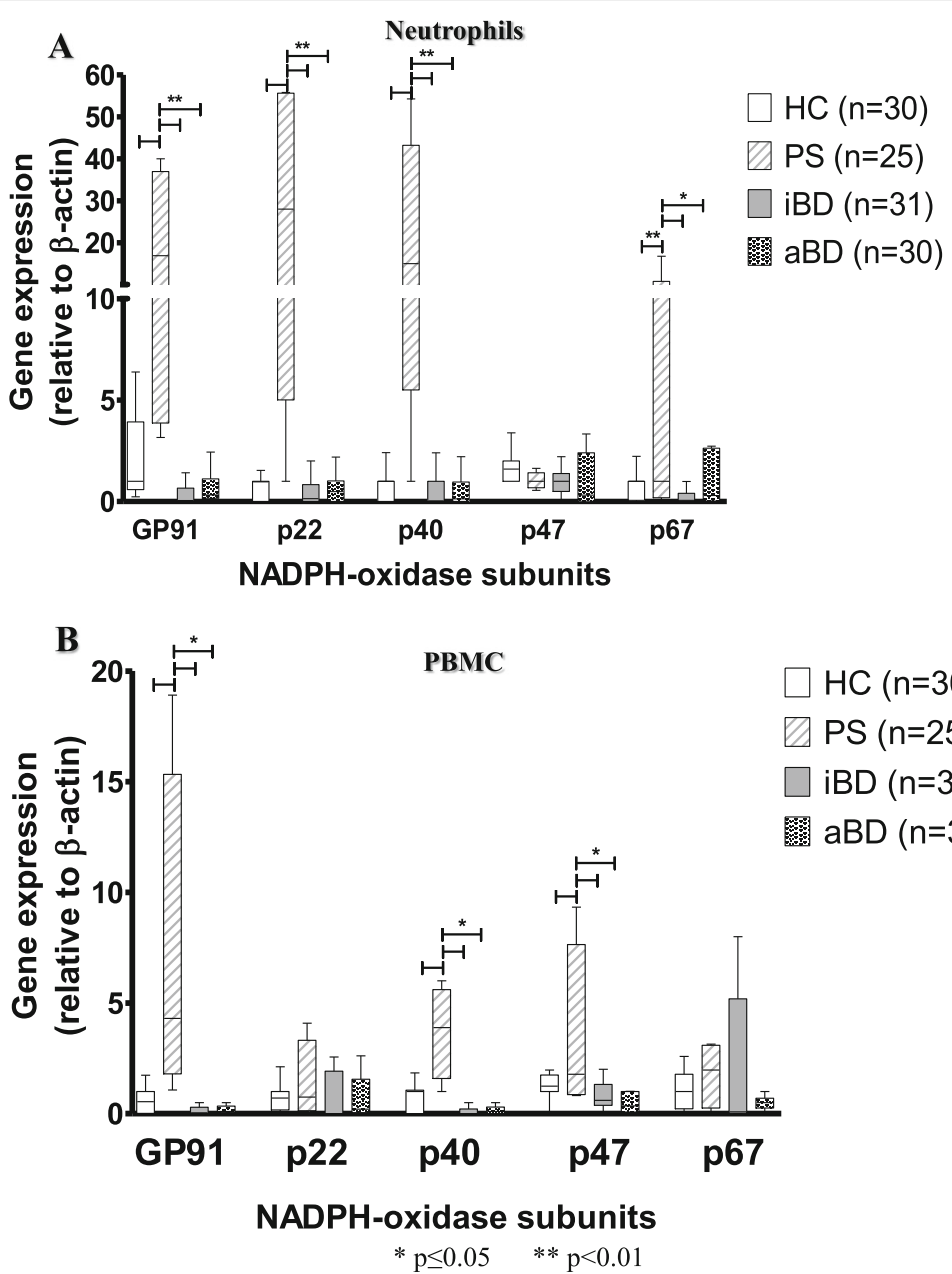

Fig. 4 Gene expression of the five nicotinamide adenine dinucleotide phosphate (NADPH) oxidase subunits (gp-91-phox, p22, p40, p47, and p67) in resting neutrophils (a) and peripheral blood mononuclear cells (PBMCs) (b) from healthy control subjects (HCs; $n=30$ ), patients with sepsis (PSs; $n=25)$, patients with inactive Behçet's disease (iBD; $n=31)$, and patients with active Behçet's disease patients (aBD; $n=30)$. Statistical analysis was performed using the Kruskal-Wallis test with the Mann-Whitney posttest

High sCD40L serum levels have been demonstrated in other rheumatic autoimmune diseases [33-36], especially in SLE [37]. By comparing the relative amount of SCD40L present in BD with that in SLE, we found sCD40L plasma levels in aSLE to be comparable to those observed in $\mathrm{BBD}$ and significantly lower than those observed in patients with $\mathrm{aBD}$, highlighting the significant background activation of this pathway in BD. Notably, the level of SCD40L expression in patients with iSLE was similar to that observed in HCs. Our data confirm and extend previous findings by demonstrating, in $\mathrm{BD}$ cells, the stimulating effect of $\mathrm{SCD} 40 \mathrm{~L}$ on NET release and oxidative burst and by providing evidence suggesting that this effect is initiated by NF-kB signaling, as previously described in mice $[14,38]$. Mac-1 may be secondarily involved in this phenomenon because this adhesion receptor complex, usually upregulated on activated myeloid cells, is overexpressed in resting BD neutrophils [15].
Platelets are the main source of sCD40L, but other cells can express and shed CD40L, including activated $\mathrm{T}$ cells. In contrast to the study by Fernández-Bello et al. [14], our study did not show abnormally high CD40L expression by activated platelets from patients with BD; differences in methodology may be the reason for this discrepancy. We used a physiologic stimulus (thrombin activation), whereas Fernández-Bello et al. [14] used a synthetic thrombin receptor-activating peptide assay. In contrast to our observations in platelets, we clearly demonstrate increased CD40L surface expression by in vitro activated $\mathrm{CD}^{+}{ }^{+} \mathrm{T}$ cells associated with increased basal gene expression by PBMCs from patients with $\mathrm{BD}$. Therefore, our hypothesis is that $\mathrm{CD}^{+}{ }^{+} \mathrm{T}$ cells from patients with $\mathrm{BD}$ constitutively present an enlarged pool of mRNA and preformed CD40L protein, which in turn is quickly expressed at the membrane surface under stress. Ultimately, activated $\mathrm{T}$ cells may also contribute to the 
Table 2 Nicotinamide adenine dinucleotide phosphate oxidase subunit protein expression in neutrophils and monocytes

\begin{tabular}{|c|c|c|c|c|c|}
\hline \multirow{2}{*}{$\begin{array}{l}\text { Cell } \\
\text { source }\end{array}$} & \multicolumn{5}{|l|}{ Stimulus } \\
\hline & None & PMA & HC plasma & iBD plasma & aBD plasma \\
\hline \multicolumn{6}{|c|}{ Neutrophils } \\
\hline \multicolumn{6}{|c|}{ gp91-phox } \\
\hline $\mathrm{HC}$ & $23.98 \pm 11.55$ & $399.71 \pm 47.86^{a}$ & $148.26 \pm 29.29$ & $261.27 \pm 32.52^{b}$ & $271.33 \pm 44.23^{b}$ \\
\hline $\mathrm{iBD}$ & $19.66 \pm 11.23$ & $402.00 \pm 71.57^{\mathrm{a}}$ & $156.95 \pm 31.23$ & $291.87 \pm 45.39^{b}$ & $297.35 \pm 22.48^{b}$ \\
\hline $\mathrm{aBD}$ & $32.68 \pm 17.61$ & $464.71 \pm 48.45^{\mathrm{a}}$ & $139.05 \pm 32.75$ & $277.88 \pm 41.76^{b}$ & $278.64 \pm 39.95^{b}$ \\
\hline \multicolumn{6}{|l|}{ p22 } \\
\hline $\mathrm{HC}$ & $20.93 \pm 11.40$ & $453.04 \pm 70.51^{a}$ & $139.25 \pm 31.37$ & $262.56 \pm 36.43^{b}$ & $281.02 \pm 53.86^{b}$ \\
\hline $\mathrm{iBD}$ & $23.72 \pm 12.25$ & $438.87 \pm 52.98^{\mathrm{a}}$ & $132.62 \pm 17.28$ & $279.12 \pm 38.67^{b}$ & $282.62 \pm 35.75^{b}$ \\
\hline $\mathrm{aBD}$ & $38.82 \pm 24.88$ & $422.75 \pm 64.76^{a}$ & $152.78 \pm 9.32$ & $288.74 \pm 30.77^{b}$ & $314.94 \pm 40.60^{b}$ \\
\hline \multicolumn{6}{|l|}{ p40 } \\
\hline $\mathrm{HC}$ & $22.73 \pm 9.96$ & $377.33 \pm 115.38^{\mathrm{a}}$ & $165.77 \pm 33.20$ & $279.88 \pm 38.13^{b}$ & $299.00 \pm 49.97^{b}$ \\
\hline $\mathrm{iBD}$ & $42.43 \pm 7.36$ & $453.37 \pm 77.82^{\mathrm{a}}$ & $133.37 \pm 16.08$ & $279.00 \pm 50.57^{b}$ & $293.12 \pm 31.47^{b}$ \\
\hline $\mathrm{aBD}$ & $28.85 \pm 12.85$ & $475.42 \pm 79.97^{\mathrm{a}}$ & $160.71 \pm 20.86$ & $274.71 \pm 55.96^{\mathrm{b}}$ & $253.00 \pm 36.56^{b}$ \\
\hline \multicolumn{6}{|l|}{ p47 } \\
\hline $\mathrm{HC}$ & $22.16 \pm 9.23$ & $383.05 \pm 69.88^{a}$ & $132.90 \pm 38.84$ & $247.97 \pm 92.38^{b}$ & $280.63 \pm 59.20^{b}$ \\
\hline $\mathrm{iBD}$ & $35.68 \pm 22.66$ & $447.75 \pm 41.11^{\mathrm{a}}$ & $151.53 \pm 29.26$ & $274.12 \pm 50.08^{b}$ & $270.12 \pm 56.07^{b}$ \\
\hline $\mathrm{aBD}$ & $21.04 \pm 7.94$ & $400.00 \pm 57.01^{\mathrm{a}}$ & $141.27 \pm 34.16$ & $282.12 \pm 16.01^{b}$ & $293.00 \pm 50.48^{b}$ \\
\hline \multicolumn{6}{|l|}{ p67 } \\
\hline $\mathrm{HC}$ & $32.78 \pm 13.00$ & $487.36 \pm 93.67^{a}$ & $162.11 \pm 32.10$ & $288.44 \pm 42.48^{b}$ & $296.11 \pm 55.36^{b}$ \\
\hline $\mathrm{iBD}$ & $36.61 \pm 15.39$ & $396.50 \pm 57.82^{\mathrm{a}}$ & $145.12 \pm 30.69$ & $289.50 \pm 46.72^{b}$ & $266.12 \pm 54.21^{b}$ \\
\hline $\mathrm{aBD}$ & $26.42 \pm 9.91$ & $425.42 \pm 50.71^{a}$ & $160.00 \pm 22.37$ & $296.71 \pm 42.42^{b}$ & $274.57 \pm 39.45^{b}$ \\
\hline \multicolumn{6}{|c|}{ Monocytes } \\
\hline \multicolumn{6}{|c|}{ gp91-phox } \\
\hline $\mathrm{HC}$ & $29.75 \pm 16.20$ & $412.02 \pm 68.52^{\mathrm{a}}$ & $154.13 \pm 19.00$ & $355.05 \pm 107.18^{b}$ & $421.50 \pm 78.28^{b}$ \\
\hline $\mathrm{iBD}$ & $16.43 \pm 5.38$ & $415.43 \pm 60.54^{\mathrm{a}}$ & $148.00 \pm 33.64$ & $318.06 \pm 17.94^{b}$ & $330.40 \pm 15.98^{b}$ \\
\hline $\mathrm{aBD}$ & $22.41 \pm 8.09$ & $468.62 \pm 30.17^{a}$ & $149.41 \pm 26.47$ & $263.51 \pm 50.51^{b}$ & $282.71 \pm 50.99^{b}$ \\
\hline \multicolumn{6}{|l|}{ p22 } \\
\hline $\mathrm{HC}$ & $21.37 \pm 12.57$ & $486.14 \pm 82.35^{\mathrm{a}}$ & $157.44 \pm 40.22$ & $267.42 \pm 34.51^{b}$ & $281.82 \pm 39.82^{b}$ \\
\hline $\mathrm{iBD}$ & $23.00 \pm 14.07$ & $442.61 \pm 44.55^{\mathrm{a}}$ & $157.41 \pm 30.28$ & $281.65 \pm 35.56^{\mathrm{b}}$ & $283.66 \pm 43.68^{b}$ \\
\hline $\mathrm{aBD}$ & $27.25 \pm 21.68$ & $414.80 \pm 33.12^{\mathrm{a}}$ & $129.20 \pm 15.01$ & $272.47 \pm 29.72^{b}$ & $235.70 \pm 53.94^{b}$ \\
\hline \multicolumn{6}{|l|}{ p40 } \\
\hline $\mathrm{HC}$ & $28.21 \pm 10.94$ & $467.00 \pm 67.57^{\mathrm{a}}$ & $147.22 \pm 25.00$ & $286.11 \pm 37.36^{\mathrm{b}}$ & $273.77 \pm 53.97^{b}$ \\
\hline $\mathrm{iBD}$ & $54.53 \pm 6.55$ & $560.12 \pm 74.73^{\mathrm{a}}$ & $142.25 \pm 30.90$ & $259.25 \pm 42.82^{b}$ & $289.25 \pm 35.70^{b}$ \\
\hline $\mathrm{aBD}$ & $45.62 \pm 9.24$ & $468.75 \pm 78.34^{a}$ & $137.00 \pm 25.80$ & $290.37 \pm 31.87^{b}$ & $301.25 \pm 44.61^{b}$ \\
\hline \multicolumn{6}{|l|}{ p47 } \\
\hline $\mathrm{HC}$ & $27.45 \pm 11.87$ & $387.52 \pm 45.42^{\mathrm{a}}$ & $155.84 \pm 17.92$ & $246.52 \pm 37.54^{b}$ & $263.57 \pm 60.32^{b}$ \\
\hline $\mathrm{iBD}$ & $23.56 \pm 15.99$ & $416.77 \pm 49.75^{\mathrm{a}}$ & $118.50 \pm 27.70$ & $278.71 \pm 35.03^{b}$ & $286.70 \pm 49.01^{b}$ \\
\hline $\mathrm{aBD}$ & $29.49 \pm 23.42$ & $427.37 \pm 63.68^{\mathrm{a}}$ & $160.71 \pm 24.88$ & $264.12 \pm 21.63^{b}$ & $262.01 \pm 38.54^{b}$ \\
\hline \multicolumn{6}{|l|}{ p67 } \\
\hline $\mathrm{HC}$ & $27.09 \pm 17.14$ & $453.77 \pm 62.69^{\mathrm{a}}$ & $160.44 \pm 27.99$ & $272.55 \pm 42.45^{b}$ & $275.22 \pm 46.01^{b}$ \\
\hline $\mathrm{iBD}$ & $29.01 \pm 12.42$ & $420.12 \pm 71.30^{\mathrm{a}}$ & $140.37 \pm 26.73$ & $281.75 \pm 38.49^{b}$ & $303.75 \pm 48.17^{b}$ \\
\hline $\mathrm{aBD}$ & $29.41 \pm 12.61$ & $447.00 \pm 67.93^{\mathrm{a}}$ & $142.50 \pm 34.80$ & $249.75 \pm 39.07^{b}$ & $269.50 \pm 33.04^{b}$ \\
\hline
\end{tabular}

Abbreviations: $a B D$ Active Behçet's disease, $H C$ Healthy control, $i B D$ Inactive Behçet's disease, PMA Phorbol 12-myristate 13-acetate

Neutrophils and monocytes were obtained from $\operatorname{HCs}(n=9)$, patients with $\mathrm{BD}(n=8)$, and patients with $\mathrm{ABD}(n=8)$, and protein expression as determined by mean fluorescence intensity was found to be increased after stimulation with BD plasma

Statistical analysis was performed using one-way analysis of variance with the Bonferroni posttest

a $p<0.05$ compared with unstimulated cells and any other stimulus

b $p<0.05$ compared with unstimulated cells and stimulation with plasma from HCs 


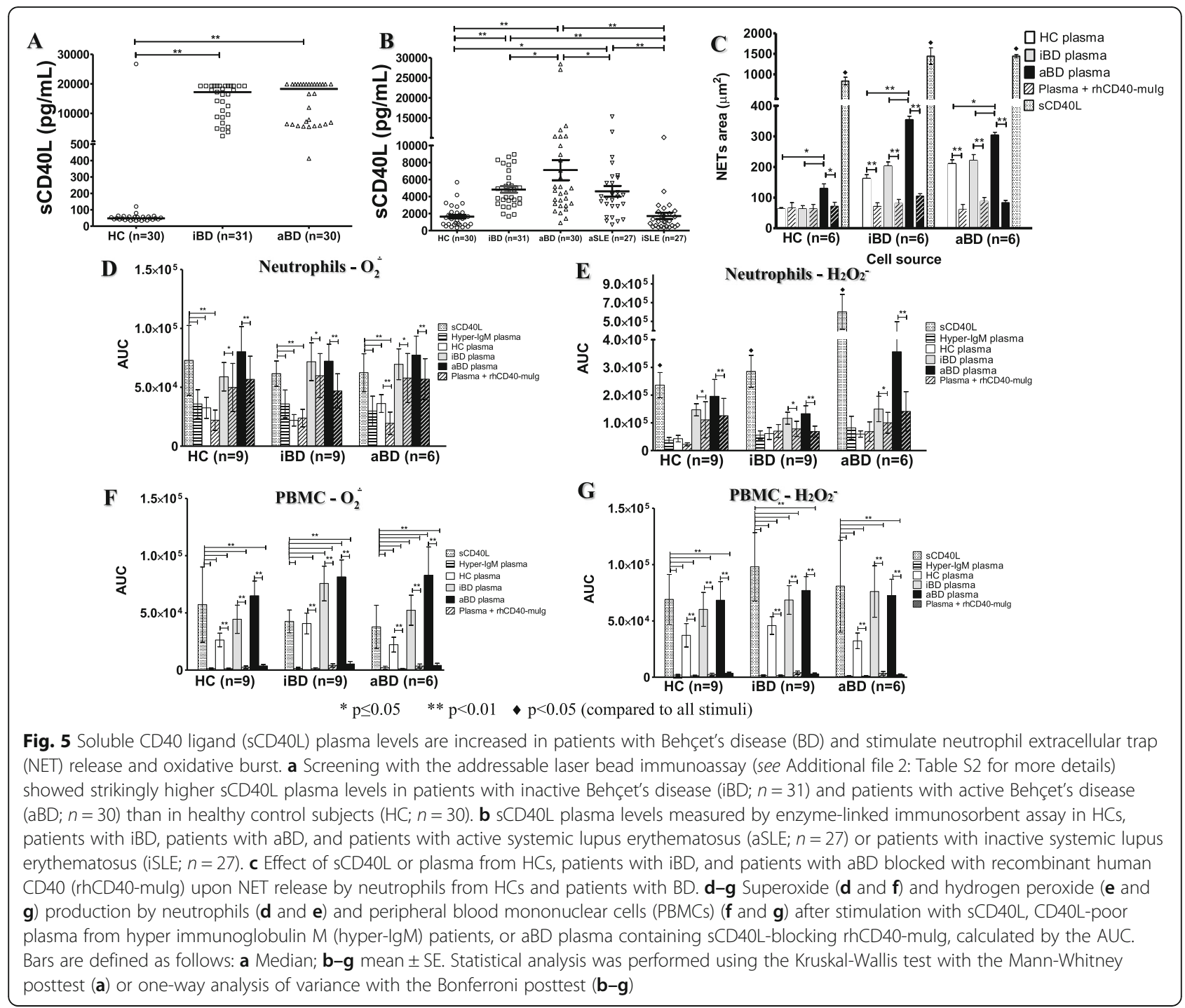

high sCD40L plasma levels observed in BD. In addition, because $\mathrm{BD}$ is primarily a mucocutaneous disorder, fibroblast and epithelial cells, especially those from the uvea, retina, and oral and genital cavities, are also candidates to be sources of sCD40L. Further studies are necessary to test this hypothesis.

The finding that resting phagocytes from patients with $\mathrm{BD}$ and $\mathrm{HCs}$ did not differ regarding oxidative profile and NADPH oxidase gene and protein expression supports the concept that phagocyte dysfunction in $\mathrm{BD}$ is not constitutional. By the same token, our results provide hints about the origin of the factors stimulating phagocytes in BD, because NADPH oxidase expression and oxidative burst activity increased after stimulation with the BD plasma pools. Interestingly, though, sCD40L blocking inhibited superoxide and hydrogen peroxide production less intensely in neutrophils than in PBMCs, suggesting the presence of additional stimulatory serum factors acting on neutrophils. Although the main contribution of the present study relies on showing the original association between $\mathrm{sCD} 40 \mathrm{~L}$ and phagocyte function in $\mathrm{BD}$, other soluble mediators were slightly but significantly increased in patients with $\mathrm{BD}$, and several others are yet to be described. Moreover, each cell type has distinct responsiveness to different stimuli, which can also explain the differences observed between neutrophils and PBMCs. Additional studies are already being designed by our group in an effort to clarify this question.

Increased NET release has previously been demonstrated in SLE [39], rheumatoid arthritis [40], and antineutrophil cytoplasmic antibody-associated vasculitis [41]. Our study demonstrates increased NET release by resting neutrophils from patients with $\mathrm{BD}$ and a further increase after stimulation with aBD plasma, indicating that circulating neutrophils from these patients have 


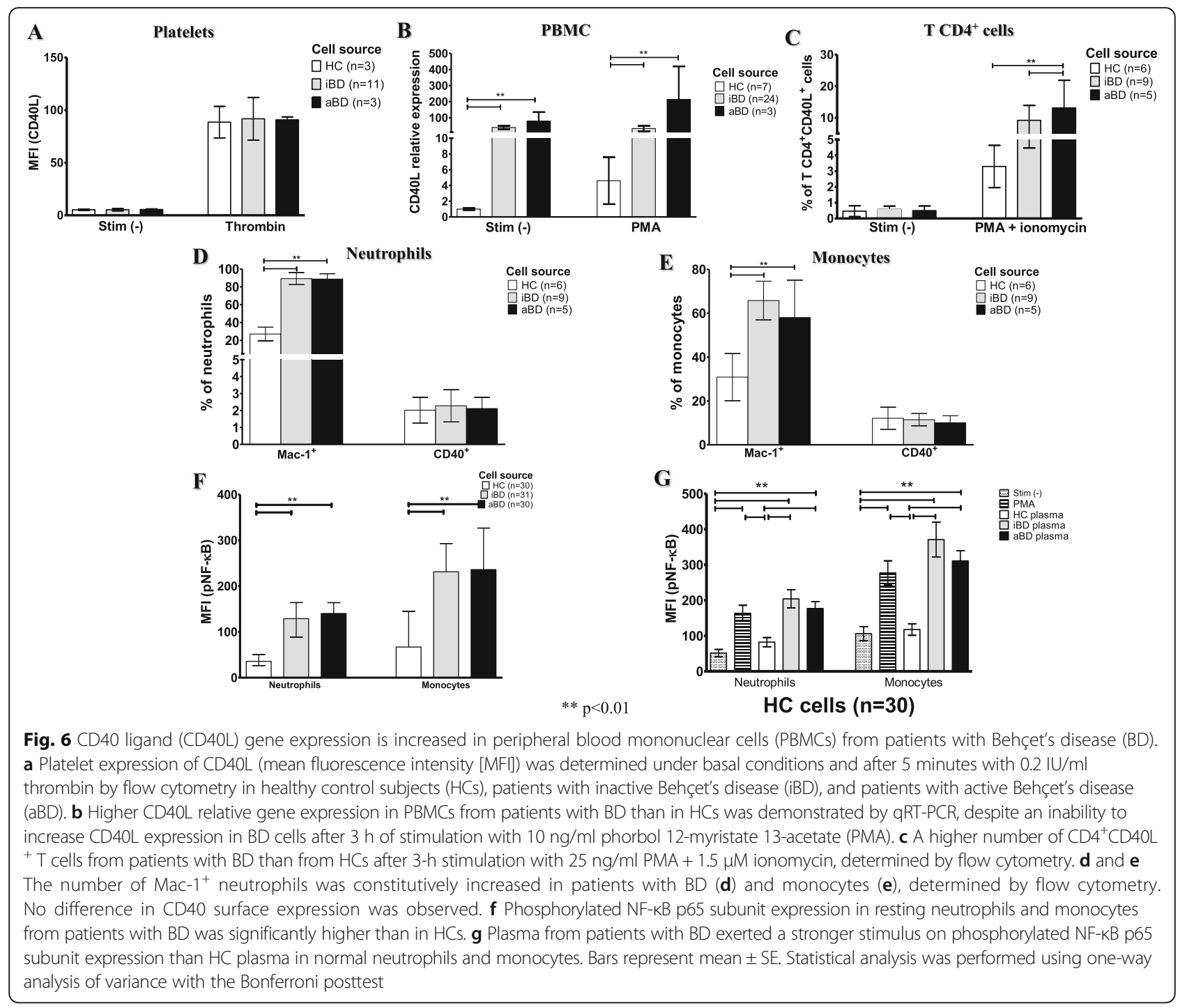

undergone some degree of activation. We hypothesize that the proinflammatory environment in $\mathrm{BD}$, especially represented by elevated sCD40L plasma levels, stimulates neutrophil activation and NET release in vivo. Recent studies suggest that NETosis also serves as a physical trail directing cell migration, especially of phagocytes, to inflammatory sites [42]. In view of the current demonstration of increased NETosis in BD, we hypothesize that this mechanism contributes to the increased neutrophil migration [8] and chemotaxis [10] observed in this disease. Further studies should address possible signaling pathways involved in sCD40L-induced NET release and phagocyte migration in BD.

The evidence provided here opens potential opportunities for the development of targeted therapies. A study in a lupus mouse model [43] and a phase I clinical study using a PEGylated anti-CD40L antibody fragment showed promising results [44]. However, previous clinical trials done to determine the efficacy of anti-CD40L therapy in transplantation [45] and immune thrombocytopenic purpura [46] were discontinued because of severe thromboembolic events probably caused by cross-linking of CD40L on platelets.

Interleukin (IL)-8 is a chemoattractant and neutrophil activator and thus would be a candidate plasma factor involved in the phagocyte activation observed in BD. This possibility is favored by pieces of evidence, including increased $I L 8$ gene expression in macrophages after stimulation with aBD plasma [47] as well as high IL-8 serum [48] and synovial concentrations in patients with BD [49]. Surprisingly, our data did not demonstrate increased IL-8 plasma levels in patients with BD, which may be related to the wide genotypic and phenotypic variation that may occur in distinct ethnic groups, suggesting that various factors associated with sCD40L may be acting in the disease's pathogenesis. Additionally, the 
multiplex screening method used may not detect small differences between the groups, constituting an independent bias.

As a pleiotropic and polygenic disease, patient heterogeneity is an important bias. Although clinical and therapeutic confounding variables did not demonstrate any interference with the parameters studied, such factors can never be completely ruled out. It should be noted that colchicine, a medication previously demonstrated to inhibit inflammasome activation [50], NF- $\mathrm{kB}$ activation [51], and superoxide production [52], had been equally administered in the iBD and aBD groups. Moreover, our cohort was constituted of a sample of the Brazilian population, which represents a unique blend of European, African, and Native American descendants. Therefore, our findings should be confirmed in studies of other ethnic groups exposed to distinct environmental conditions because our patients may represent only a fraction of the cases and a piece in the BD pathophysiologic enigma.

\section{Conclusions}

The present study shows that plasma from patients with BD exerted a strong stimulus on the production of reactive oxygen species and NET release, and it provides evidence indicating that this effect is induced by $\mathrm{SCD} 40 \mathrm{~L}$. In addition, it provides evidence that resting neutrophils from patients with BD display increased NET-releasing activity. These preliminary results suggest new possibilities for further exploring the role of the CD40/CD40L pathway in phagocyte functional abnormalities in $\mathrm{BD}$ pathophysiology, and they may suggest novel therapeutic targets for this disease.

\section{Additional files}

Additional file 1: Table S1. Genes and primers evaluated by qRT-PCR. (PDF $102 \mathrm{~kb}$ )

Additional file 2: Table S2. Plasma levels of 64 cytokines and 13 soluble receptors from patients with active $(\mathrm{aBD})$, patients with inactive Behçet's disease (iBD), and healthy control subjects $(\mathrm{HC})$ determined by addressable laser bead immunoassay. (PDF $249 \mathrm{~kb}$ )

Additional file 3: Figure S1. CD40L expression is similar on monocytes and $C D 8^{+} T$ cells from patients with Behçet's disease. Percentages of CD8 ${ }^{+} \mathrm{CD}_{40 \mathrm{~L}}{ }^{+} \mathrm{T}$ cells $(\mathbf{a})$ and $\mathrm{CD}_{40 \mathrm{~L}}{ }^{+}$monocytes (b) were determined under basal conditions and after 3-h stimulation with $1.5 \mu \mathrm{M}$ ionomycin and/or $25 \mathrm{ng} / \mathrm{ml}$ PMA by flow cytometry in healthy control subjects (HC), patients with inactive Behçet's disease (iBD), and patients with active Behçet's disease (aBD). No difference in $\mathrm{CD} 4 \mathrm{~L}^{+}$surface expression was observed. (PDF $200 \mathrm{~kb}$ )

\section{Abbreviations}

aBD: Active Behçet's disease; ANOVA: Analysis of variance; aSLE: Active pediatric systemic lupus erythematosus; BD: Behçet's disease; cDNA: Complementary DNA; CNS: Central nervous system; ELISA: Enzymelinked immunosorbent assay; HC: Healthy control; HlgM: Hyper immunoglobulin M; iBD: Inactive Behçet's disease; IL: Interleukin; iSLE: Inactive pediatric systemic lupus erythematosus; MFI: Mean fluorescence intensity; mRNA: Messenger RNA; NADPH: Nicotinamide adenine dinucleotide phosphate; NET: Neutrophil extracellular trap; PBMC: Peripheral blood mononuclear cell; PE: Phycoerythrin; PMA: Phorbol 12-myristate 13acetate; PS: Patient with sepsis; rhCD40-mulg: Recombinant CD40; sBRBDCAF: Simplified Behçet's Disease Current Activity Form adapted for Portuguese by the Sociedade Brasileira de Reumatologia; sCD40L: Soluble CD40 ligand; SLE: Systemic lupus erythematosus; TNF: Tumor necrosis factor

\section{Acknowledgements}

The authors thank Dr. Arturo Zychlinsky (Max Planck Institute for Infection Biology, Berlin, Germany), who kindly provided aliquots of the murine antihuman histone $\mathrm{H} 2 \mathrm{~A} / \mathrm{B}$ used for NET release quantification.

\section{Funding}

This study was supported by Fundação de Amparo à Pesquisa do Estado de São Paulo (FAPESP grant 2011/50292-2); by a research and development grant from Fleury Group (12619); and by Brazilian National Council for Scientific and Technological Development (CNPq) grant 233205/2014-4 (to SFP), grant 476356/2008-3 (to LECA), and grant 306902/2013-3 (to ACN).

\section{Availability of data and materials}

All data generated or analyzed during this study were fully available to all authors and are currently included in this published article and its supplementary information files.

\section{Authors' contributions}

SFP designed the project, processed all the samples, participated in every experiment, analyzed and interpreted all clinical and experimental data, and wrote the manuscript. PVSP and VCdS participated in flow cytometry and NET assays. MVdB, BS, and MLVO performed and interpreted the addressable laser beads immunoassay. AMS collected and analyzed the SLE group data. AWSdS collected BD samples, helped with designing the study, analyzed and interpreted all data, and was a major contributor to the writing of the manuscript. HDO, TRT, ACN, and LECA helped with designing the study and analyzed and interpreted all data. All authors read and approved the final manuscript.

\section{Ethics approval and consent to participate}

The research was approved by the Universidade Federal de São Paulo (UNIFESP) Ethics Committee (CEP 0013/11) and by the Seattle Children's Institutional Review Board. All necessary consent from patients and their responsible guardians involved in the study was obtained, including consent to participate in the study itself.

\section{Consent for publication \\ Not applicable.}

\section{Competing interests}

The authors declare that they have no competing interests.

\section{Publisher's Note}

Springer Nature remains neutral with regard to jurisdictional claims in published maps and institutional affiliations.

\section{Author details}

${ }^{1}$ Division of Rheumatology, Escola Paulista de Medicina, Federal University of Sao Paulo, Rua Botucatu 740, $3^{\circ}$ Andar, 04023-062 Sao Paulo, SP, Brazil. ${ }^{2}$ Fleury Group - Research and Development, Avenida General Valdomiro de Lima, 508, 04344-070 Sao Paulo, SP, Brazil. ${ }^{3}$ Seattle Children's Research Institute, University of Washington and Center for Immunity and Immunotherapies, 1900 9th Avenue, JMB-7, Seattle, WA 98101, USA. ${ }^{4}$ Department of Immunology, Institute of Biomedical Sciences, University of Sao Paulo, Avenida Professor Lineu Prestes, 2415, 03178-200 Sao Paulo, SP, Brazil. ${ }^{5}$ Department of Pathology, Federal University of Maranhao, Avenida dos Portugueses, 65065-545 Sao Luiz, MA, Brazil. 'Department of Biochemistry and Molecular Biology, Escola Paulista de Medicina, Federal University of Sao Paulo, Rua Três de Maio, 100, $5^{\circ}$ Andar, 04044-020 Sao Paulo, SP, Brazil. 
Received: 8 May 2017 Accepted: 25 September 2017

Published online: 19 October 2017

\section{References}

1. Gül A. Behçet's disease: an update on the pathogenesis. Clin Exp Rheumatol. 2001;19(5 Suppl 24):S6-12.

2. Shimizu J, Takai K, Fujiwara N, Arimitsu N, Ueda Y, Wakisaka S, Yoshikawa H, Kaneko F, Suzuki T, Suzuki N. Excessive CD4 ${ }^{+} T$ cells co-expressing interleukin-17 and interferon- $\gamma$ in patients with Behçet's disease. Clin Exp Immunol. 2012;168(1):68-74.

3. Takeno M, Kariyone A, Yamashita N, Takiguchi M, Mizushima Y, Kaneoka H, Sakane T. Excessive function of peripheral blood neutrophils from patients with Behcet's disease and from HLA-B51 transgenic mice. Arthritis Rheum. 1995;38(3):426-33.

4. Eksioglu-Demiralp E, Direskeneli H, Kibaroglu A, Yavuz S, Ergun T, Akoglu T. Neutrophil activation in Behcet's disease. Clin Exp Rheumatol. 2001;19(5 Suppl 24):S19-24.

5. Atalay G, Eksioglu-Demiralp E, Akoglu T, Direskeneli $H$. The effects of nitric oxide donors and inhibitors on neutrophil functions in Behcet's disease. Clin Exp Rheumatol. 2002;20(4 Suppl 26):S17-20.

6. Tekeli A, Tekeli O, Ozdemir O. In vitro candidacidal effect of polymorphonuclear neutrophils of Behçet's patients with or without ocular involvement. APMIS. 2001;109(2):108-12

7. Verity DH, Wallace GR, Vaughan RW, Stanford MR. Behçet's disease: from Hippocrates to the third millennium. Br J Ophthalmol. 2003;87(9):1175-83.

8. Carletto A, Pacor ML, Biasi D, Caramaschi P, Zeminian S, Bellavite P, Bambara LM. Changes of neutrophil migration without modification of in vitro metabolism and adhesion in Behcet's disease. J Rheumatol. 1997;24(7): 1332-6.

9. Perazzio SF, Soeiro-Pereira PV, de Souza AW, Condino-Neto A, Andrade LE. Behçet's disease heterogeneity: cytokine production and oxidative burst of phagocytes are altered in patients with severe manifestations. Clin Exp Rheumatol. 2015;33(6 Suppl 94):S85-95.

10. Neves FS, Carrasco S, Goldenstein-Schainberg C, Goncalves CR, de Mello SB. Neutrophil hyperchemotaxis in Behcet's disease: a possible role for monocytes orchestrating bacterial-induced innate immune responses. Clin Rheumatol. 2009:28(12):1403-10.

11. Yoshida T, Tanaka M, Sotomatsu A, Okamoto K, Hirai S. Serum of Behcet's disease enhances superoxide production of normal neutrophils. Free Radic Res. 1998;28(1):39-44.

12. Pietravalle F, Lecoanet-Henchoz S, Blasey H, Aubry JP, Elson G, Edgerton MD, Bonnefoy JY, Gauchat JF. Human native soluble CD40L is a biologically active trimer, processed inside microsomes. J Biol Chem. 1996;271(11):5965-7.

13. Hassan GS, Merhi Y, Mourad W. CD40 ligand: a neo-inflammatory molecule in vascular diseases. Immunobiology. 2012;217(5):521-32.

14. Fernández Bello I, Álvarez MT, López-Longo FJ, Arias-Salgado EG, Martín M Jiménez-Yuste V, de la Rúa Rodríguez A, Butta NV. Platelet soluble CD40L and matrix metalloproteinase 9 activity are proinflammatory mediators in Behçet disease patients. Thromb Haemost. 2012;107(1):88-98.

15. Jin R, Yu S, Song Z, Zhu X, Wang C, Yan J, Wu F, Nanda A, Granger DN, Li G. Soluble CD40 ligand stimulates CD40-dependent activation of the $\beta 2$ integrin Mac-1 and protein kinase C zeda (PKC ) in neutrophils: implications for neutrophil-platelet interactions and neutrophil oxidative burst. PLoS One. 2013;8(6):e64631

16. Kastner DL, Aksentijevich I, Goldbach-Mansky R. Autoinflammatory disease reloaded: a clinical perspective. Cell. 2010;140(6):784-90.

17. International Study Group for Behçet's Disease. Criteria for diagnosis of Behçet's disease. Lancet. 1990;335(8697):1078-80.

18. de Souza NF, Muniz Caldas CA, de Martins Medeiros D, de Bertacini Moraes JC, Gonçalves CR. Cross-cultural adaptation of simplified version(s) of Behçet's Disease Current Activity Form (BDCAF) and comparison between two different instruments with Brazilian versions for evaluating Behçet's Disease Activity: BR-BDCAF and BR-BDCAF(s) [in Portuguese]. Rev Bras Reumatol. 2009:49(1):20-31.

19. Bone RC, Balk RA, Cerra FB, Dellinger RP, Fein AM, Knaus WA, Schein RM, Sibbald WJ, ACCP/SCCM Consensus Conference Committee. Definitions for sepsis and organ failure and guidelines for the use of innovative therapies in sepsis. Chest. 1992;101(6):1644-55.

20. Hochberg MC. Updating the American College of Rheumatology revised criteria for the classification of systemic lupus erythematosus. Arthritis Rheum. 1997:40(9):1725.
21. Bombardier C, Gladman DD, Urowitz MB, Caron D, Chang CH, Committee on Prognosis Studies in SLE. Derivation of the SLEDAl: a disease activity index for lupus patients. Arthritis Rheum. 1992;35(6):630-40.

22. Soeiro-Pereira PV, Falcai A, Kubo CA, Oliveira-Júnior EB, Marques OC, Antunes E, Condino-Neto A. BAY 41-2272, a soluble guanylate cyclase agonist, activates human mononuclear phagocytes. Br J Pharmacol. 2012; 166(5):1617-30

23. Hatanaka E, Levada-Pires AC, Pithon-Curi TC, Curi R. Systematic study on ROS production induced by oleic, linoleic, and gamma-linolenic acids in human and rat neutrophils. Free Radic Biol Med. 2006;41(7):1124-32.

24. Maguire $\mathrm{O}, \mathrm{O}^{\prime}$ Loughlin $\mathrm{K}$, Minderman $\mathrm{H}$. Simultaneous assessment of NF-KB/ p65 phosphorylation and nuclear localization using imaging flow cytometry. Immunol Methods. 2015:423:3-11.

25. Fuchs TA, Abed U, Goosmann C, Hurwitz R, Schulze I, Wahn V, Weinrauch $Y$, Brinkmann $V$, Zychlinsky A. Novel cell death program leads to neutrophil extracellular traps. J Cell Biol. 2007;176(2):231-41.

26. Cabral-Marques O, Schimke LF, Pereira PV, Falcai A, de Oliveira JB, Hackett MJ, Errante PR, Weber CW, Ferreira JF, Kuntze G, et al. Expanding the clinical and genetic spectrum of human CD40L deficiency: the occurrence of paracoccidioidomycosis and other unusual infections in Brazilian patients. J Clin Immunol. 2012:32(2):212-20.

27. Desai-Mehta A, Lu L, Ramsey-Goldman R, Datta SK. Hyperexpression of CD40 ligand by B and T cells in human lupus and its role in pathogenic autoantibody production. J Clin Invest. 1996;97(9):2063-73.

28. Katsiari CG, Liossis SN, Souliotis VL, Dimopoulos AM, Manoussakis MN, Sfikakis PP. Aberrant expression of the costimulatory molecule CD40 ligand on monocytes from patients with systemic lupus erythematosus. Clin Immunol. 2002;103(1):54-62

29. Lee R. Revisiting the role of SCD40L as an inflammatory biomarker in a clinical model of acute myocardial infarction. Circ Res. 2015;116(4):e26.

30. Wang JH, Zhang YW, Zhang P, Deng BQ, Ding S, Wang ZK, Wu T, Wang J. CD40 ligand as a potential biomarker for atherosclerotic instability. Neurol Res. 2013;35(7):693-700.

31. Santilli F, Liani R, Di Fulvio P, Formoso G, Simeone P, Tripaldi R, Ueland T, Aukrust $P$, Davì $G$. Increased circulating resistin is associated with insulin resistance, oxidative stress and platelet activation in type 2 diabetes mellitus. Thromb Haemost. 2016;116(6):1089-99.

32. Mege JL, Dilsen N, Sanquedolce V, Gul A, Bongrand P, Roux H, Ocal L, Inanç M, Capo C. Overproduction of monocyte derived tumor necrosis factor a, interleukin (IL) 6, IL-8 and increased neutrophil superoxide generation in Behçet's disease: a comparative study with familial Mediterranean fever and healthy subjects. J Rheumatol. 1993;20(9):1544-9.

33. Sellam J, Proulle V, Jüngel A, Ittah M, Miceli Richard C, Gottenberg JE, Toti F, Benessiano J, Gay S, Freyssinet JM, et al. Increased levels of circulating microparticles in primary Sjögren's syndrome, systemic lupus erythematosus and rheumatoid arthritis and relation with disease activity. Arthritis Res Ther 2009:11(5):R156.

34. Pamuk GE, Vural O, Turgut B, Demir M, Pamuk ON, Cakir N. Increased platelet activation markers in rheumatoid arthritis: are they related with subclinical atherosclerosis? Platelets. 2008;19(2):146-54.

35. Komura K, Sato S, Hasegawa M, Fujimoto M, Takehara K. Elevated circulating CD40L concentrations in patients with systemic sclerosis. J Rheumatol. 2004:31(3):514-9.

36. Jinnin M, Ihn H, Yazawa N, Asano Y, Yamane K, Tamaki K. Elevated circulating soluble CD40 ligand in patients with mixed connective tissue disease. Clin Rheumatol. 2003;22(1):37-9.

37. Ciferská H, Horák P, Hermanová Z, Ordeltová M, Zadrazil J, Tichý T, Scudla V. The levels of SCD30 and of SCD40L in a group of patients with systemic lupus erythematodes and their diagnostic value. Clin Rheumatol. 2007:26(5):723-8.

38. Rahman M, Zhang S, Chew M, Ersson A, Jeppsson B, Thorlacius H. Plateletderived CD40L (CD154) mediates neutrophil upregulation of Mac-1 and recruitment in septic lung injury. Ann Surg. 2009;250(5):783-90.

39. Hakkim A, Furnrohr BG, Amann K, Laube B, Abed UA, Brinkmann V, Herrmann M, Voll RE, Zychlinsky A. Impairment of neutrophil extracellular trap degradation is associated with lupus nephritis. Proc Natl Acad Sci U S A. 2010;107(21):9813-8.

40. Sur Chowdhury C, Giaglis S, Walker UA, Buser A, Hahn S, Hasler P. Enhanced neutrophil extracellular trap generation in rheumatoid arthritis: analysis of underlying signal transduction pathways and potential diagnostic utility. Arthritis Res Ther. 2014;16(3):R122. 
41. Nakazawa D, Shida H, Tomaru U, Yoshida M, Nishio S, Atsumi T, Ishizu A. Enhanced formation and disordered regulation of NETs in myeloperoxidaseANCA-associated microscopic polyangiitis. J Am Soc Nephrol. 2014;25(5):990-7.

42. Yipp BG, Kubes P. NETosis: how vital is it? Blood. 2013;122(16):2784-94.

43. Xie JH, Yamniuk AP, Borowski V, Kuhn R, Susulic V, Rex-Rabe S, Yang X, Zhou X, Zhang Y, Gillooly K, et al. Engineering of a novel anti-CD40L domain antibody for treatment of autoimmune diseases. J Immunol. 2014; 192(9):4083-92.

44. Tocoian A, Buchan P, Kirby H, Soranson J, Zamacona M, Walley R, Mitchell N, Esfandiari E, Wagner F, Oliver R. First-in-human trial of the safety, pharmacokinetics and immunogenicity of a PEGylated anti-CD40L antibody fragment (CDP7657) in healthy individuals and patients with systemic lupus erythematosus. Lupus. 2015;24(10):1045-56.

45. Wood SC, Lu G, Burrell BE, Bishop DK. Transplant acceptance following antiCD4 versus anti-CD40L therapy: evidence for differential maintenance of graft-reactive T cells. Am J Transplant. 2008;8(10):2037-48.

46. Patel VL, Schwartz J, Bussel JB. The effect of anti-CD40 ligand in immune thrombocytopenic purpura. Br J Haematol. 2008;141(4):545-8.

47. Alpsoy E, Kodelja V, Goerdt S, Orfanos CE, Zouboulis CC. Serum of patients with Behcet's disease induces classical (pro-inflammatory) activation of human macrophages in vitro. Dermatology. 2003;206(3):225-32.

48. Zouboulis CC, Katsantonis J, Ketteler R, Treudler R, Kaklamani E, Hornemann S, Kaklamanis P, Orfanos CE. Adamantiades-Behcet's disease: interleukin-8 is increased in serum of patients with active oral and neurological manifestations and is secreted by small vessel endothelial cells. Arch Dermatol Res. 2000;292(6):279-84.

49. Ertenli I, Kiraz S, Calguneri M, Celik I, Erman M, Haznedaroglu IC, Kirazli S. Synovial fluid cytokine levels in Behcet's disease. Clin Exp Rheumatol. 2001; 19(5 Suppl 24):S37-41.

50. Martinon F, Pétrilli V, Mayor A, Tardivel A, Tschopp J. Gout-associated uric acid crystals activate the NALP3 inflammasome. Nature. 2006:440(7081):237-41.

51. Jackman RW, Rhoads MG, Cornwell E, Kandarian SC. Microtubulemediated NF-KB activation in the TNF-a signaling pathway. Exp Cell Res. 2009;315(19):3242-9.

52. Chia EW, Grainger R, Harper JL. Colchicine suppresses neutrophil superoxide production in a murine model of gouty arthritis: a rationale for use of lowdose colchicine. Br J Pharmacol. 2008;153(6):1288-95.

\section{Submit your next manuscript to BioMed Central and we will help you at every step:}

- We accept pre-submission inquiries

- Our selector tool helps you to find the most relevant journal

- We provide round the clock customer support

- Convenient online submission

- Thorough peer review

- Inclusion in PubMed and all major indexing services

- Maximum visibility for your research

Submit your manuscript at www.biomedcentral.com/submit 